\title{
EMISSIONS AND PERFORMANCE CHARACTERISTICS OF AN SI ENGINE WITH BIOGAS FUEL AT DIFFERENT $\mathrm{CO}_{2}$ RATIOS
}

\author{
Yasin Karagöz*
}

\begin{abstract}
Nowadays increasing emission regulations and environmental concerns have led to the use of alternative fuels in internal combustion engines. Biogas is an alternative fuel that can be produced with clean, green and natural resources. In this study, a single cylinder, four stroke SI engine was operated at stoichiometric conditions, $2800 \mathrm{rpm}$ constant engine speed with biogas fuel at different ratios. As biogas fuel, methane $\left(\mathrm{CH}_{4}\right)$ and $\mathrm{CO}_{2}$ were used during engine tests. Test results which were taken by using only gasoline were compared with the results obtained by using biogas fuel at different $\mathrm{CO}_{2}$ ratios $(10 \%, 20 \%, 30 \%$ and $40 \%$ by volume). Although it was determined specific $\mathrm{CO}$ emissions decrease and THC emissions slightly increases with the increasing $\mathrm{CO}_{2}$ ratio, it is foreseen that the increase in THC emissions can be prevented by the use of three way catalytic converter. Although the $\mathrm{NO}_{\mathrm{x}}$ emissions increase with the use of biogas compared to gasoline, it was significantly reduced by the increased $\mathrm{CO}_{2}$ rate in the biogas fuel, the $\mathrm{CO}_{2}$ 's heat carrying capacity and reducing the $\mathrm{O}_{2}$ availability of the fuel. On the other hand, because of the high cost of purification process of biogas and after-treatment equipment, it is foreseen that use of biogas at high ratio of $\mathrm{CO}_{2}$ in SI engines will be advantageous in terms of $\mathrm{NO}_{\mathrm{x}}$ emissions.
\end{abstract}

Keywords: Biogas, $\mathrm{CO}_{2}$, Methane, SI Engine, Emissions, Combustion

\section{INTRODUCTION}

Nowadays, as the number of vehicles increases, the percentage of diesel vehicles in the vehicle market increases [1]. In 2016, the market of diesel vehicles have 49\% share among all vehicles in European countries [2]. In this case, the emission of $\mathrm{NO}_{\mathrm{x}}$ and $\mathrm{PM}$ emissions increases, affecting the environment and human health negatively [3]. Due to this reason, several steps have been taken in recent years to reduce the number of diesel vehicles. As an alternative to diesel vehicles, electric and Fuel Cell vehicles are targeted to be presented to the market [4]. However, because of the high cost and short life spans of PEM fuel cells and high cost of purification of hydrogen and hydrogen storage problems avoids the use of fuel cells in vehicles [5]. On the other hand, because of the need of improvement at current battery technology and the inadequacy of charge stations prevents the widespread use of these systems in the near future [6]. Due to this reason, it is foreseen that fuel cells will be used to supply very small units' batteries and increase their range which can be used as range extender in small powers and operated as both serial hybrids and parallel hybrids when necessary. In the near future, the use of environmentally friendly, low-cost and alternative gas fuels in SI engines will gain great importance. Because of this reasons, biogas emerges as a clean and environmentally friendly alternative fuel containing methane, $\mathrm{CO}_{2}$ and other gases that can be produced from natural sources [7]. Due to the methane in its content, biogas is a environmentally friendly fuel, which has low $\mathrm{C} / \mathrm{H}$ ratio [8]. Because of the methane in its content, the use of biogas in in SI engines provides great benefit in terms of emissions [9].

Related studies in the literature on the use of biogas in SI engines are given below:

Karagoz et al. [10] used an ANN model for a spark ignition engine with use of different methane $\left(\mathrm{CH}_{4}\right)$ ratios to estimate engine performance data. The study shows that with the increase in methane concentration, positive effect is seen in volumetric efficiency but a dramatic decrease occurs in thermal efficiency. Despite that there isn't any observable change in brake specific fuel consumption.

Wang et al. [11] studied the effect of methane content to $\mathrm{NO}_{\mathrm{x}}$ emissions and indicated thermal efficiency in a biogas fuelled spark ignition engine. It is included that increase in methane content in biogas have positive effect in both indicated thermal efficiency and $\mathrm{NO}_{\mathrm{x}}$ emissions. 
Shin et al. [12] studied the effect of using biogas in a small spark ignition engine at different compression ratio and various $\mathrm{CO}_{2}$ dilution (0\%-50\%) on engine performance. The results show that, engine performance increases by using biogas with decreasing $\mathrm{CO}_{2}$ dilution.

Nadaleti et al. [13] made experiments tos see the effect of biogas-syngas dual fuel in a SI engine on engine emission characteristics. The results show that the use of biogas fuel decreases $\mathrm{NO}_{\mathrm{x}}$ emissions with a increase $\mathrm{HC}$ emissions.

Porpatham et al. [14] investigated the effect of increased oxygen concentration of intake air on engine performance, emissions and combustion in a biogas fuelled spark ignition engine. At higher oxygen levels, an observable improvement was seen in brake thermal efficiency and brake power. With higher oxygen concentration, $\mathrm{NO}_{\mathrm{x}}$ emissions increases, but $\mathrm{HC}$ and $\mathrm{CO}_{2}$ emissions decreases. There is also an improvement in thermal efficiency as a result of enchancement in combustion.

Yadav et al. [15] studied exhaust emissions characteristics of a biogas operated automotive SI engine experimentally. Experiments were performed with \%100 biogas fuel via petrol. With the comparison of petrol, the results shows that the use of biogas makes reduction in $\mathrm{NO}_{\mathrm{x}}$ and $\mathrm{CO}$ emissions and causes negligible $\mathrm{CO}$ emissions.

Considering the work done so far in the literature, it has been found that there is not enough work on the performance and emissions effects of using biogas with different $\mathrm{CO}_{2}$ contents directly on SI engines. In addition, the emission and performance impact of using biogas at different $\mathrm{CO}_{2}$ ratios in SI engines has not been investigated because the naturally purifiable biogas fuel refinement is costly and $\mathrm{CO}_{2}$ in the content of biogas has a high heat transfer capacity and low $\mathrm{O}_{2}$ availability. It is known that biogas usage in SI engines may have some negative impact on thermal efficiency and mean effective pressure. However, decreasing the toxic emissions, such as $\mathrm{NO}_{\mathrm{x}}$, to the limits determined by the stringent emission regulations requires high cost after-treatment equipments. Because of being a good alternative to reduce the emissions, the research of biogas usage which has different $\mathrm{CO}_{2}$ ratios on $\mathrm{SI}$ engines is performed in this study.

\section{TEST METHODOLOGY}

Schematic diagram of test system is shown in Figure 1. A single cylinder SI engine is used in the experiments. Engine is loaded with an $8 \mathrm{~kW}$ AC dynamometer. Fuel system consists of a methane gas tank which is connected to intake and exhaust system of the test engine. Details of the test system is given in the next subsection.

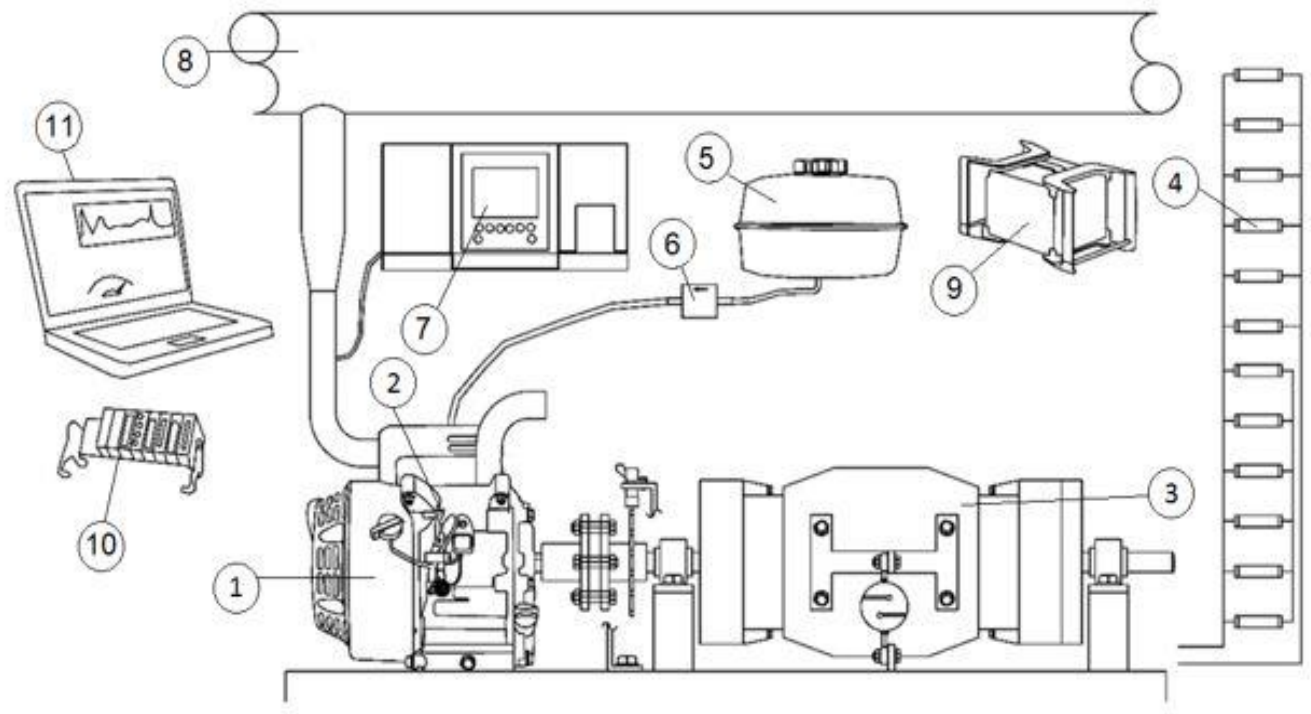

1. Test engine 2. Pressure sensor 3. Dynamometer 4. External resistive load banks 5. Gasoline tank 6. Gasoline flowmeter 7. Exhaust gas analyser 8. Exhaust vantilation system 9. Kibox combustion analyser 10. NI data acquisition device 11. Personal computer for data recording and post processing

Figure 1. Schematic diagram of engine test system 


\section{Test Setup}

Experiments were performed on a single cylinder, $270 \mathrm{cc}$, four stroke, naturally aspirated, SI engine. Engine was operated first with only gasoline then with methane at different $\mathrm{CO}_{2}$ contents $(10 \%, 20 \%, 30 \%$, $40 \%)$. All the tests were carried out at constant speed $(2800 \mathrm{rpm})$ and repeated three times.

A miniature oval gear type fuel meter was used to measure gasoline consumption. New-flow, TLF series hotwire type mass flow meter was preferred to measure methane and $\mathrm{CO}_{2}$ gas consumption. Mass flow rate of intake air was measured by a mass flow meter. AVL Digas 4000 was used to carry out the emission measurements. Calculation method which is announced by VDMA exhaust emission legislation for diesel and gas engines was used for the calculation of specific emissions by using gasoline, $\mathrm{CO}_{2}+\mathrm{CH}_{4}$ and intake air mass flow rates [16].

Crank angle position and engine speed was obtained with use of a proximity sensor and an incremental type encoder. In order to measure in-cylinder pressure, Kistler 6118B in-cylinder pressure transducer, which can also be used as spark plug was fixed to the engine head instead of original spark plug of the SI engine. Then obtained in-cylinder pressure data were processed by Kistler Kibox combustion analyzer device.

\section{Engine and Dynamometer}

A $270 \mathrm{cc}$, single cylinder, four stroke, naturally aspirated, SI engine was used during the tests. Methane and $\mathrm{CO}_{2}$ gas tanks were installed to the intake port of the test engine. Test engine was loaded by a $8 \mathrm{~kW} \mathrm{AC}$ dynamometer. Detailed information of test system can be seen in Table 1. Tests were performed in Yildiz Technical University, Internal Combustion Engines Laboratory. All of the measurement devices and test equipments in Internal Combustion Engines Laboratory of Yıldız Technical University are calibrated and certificated by the authorized companies in Istanbul.

Table 1. Engine specs and dynamometer features

\begin{tabular}{|l|l|}
\hline \multicolumn{2}{|c|}{ Engine Specs } \\
\hline Engine manufacturer & Honda \\
\hline Number of cylinders & 1 \\
\hline Bore $\times$ stroke $[\mathrm{mm}]$ & $77 \times 58$ \\
\hline Cylinder volume $\left[\mathrm{cm}^{3}\right]$ & 270 \\
\hline Aspiration & Natural \\
\hline Compression ratio & $8.5: 1$ \\
\hline Net power $[\mathrm{kW}]$ & $6.3 @ 3600 \mathrm{rpm}$ \\
\hline Recommended speed range $[\mathrm{rpm}]$ & $2000-3500$ \\
\hline Cooling & Air \\
\hline \multicolumn{2}{|c|}{ Dynamometer Features } \\
\hline Power $[\mathrm{kVA}][\mathrm{kW}]$ & 8 \\
\hline
\end{tabular}

Test Procedure

Two independent tests were performed in this study sequentially,

- Firstly, $\mathrm{CO}_{2}$ and $\mathrm{CH}_{4}$ gas tanks were equipped to the intake system of the test engine. Engine tests were performed with methane. $\mathrm{CO}_{2}$ was fed into intake manifold as supplementary fuel at 4 different ratios $(10 \%, 20 \%, 30 \%, 40 \%)$. All tests were conducted at constant speed (2800 rpm). Then,

- The SI engine were operated using only gasoline as fuel running at constant engine speed (2800 rpm).

\section{DATA PROCESSING}

In order to obtain engine performance and combustion analysis, data which were collected form sensors were used. For the calculation, following equations were used:

$$
\dot{m}_{B}=\left[\dot{v}_{B} \frac{2}{3} x \frac{1}{1000 x 60} x \rho_{B}\right]
$$


where, $\dot{m}_{B}$ is mass flow rate of biogas $\left(\mathrm{kg} / \mathrm{m}^{3}\right), \dot{v}_{B}$ is measured volume flow rate of biogas, $\rho_{B}$ is density of biogas $\left(\mathrm{kg} / \mathrm{m}^{3}\right)$.

The equations [17] used to calculate the indicated engine power and indicated engine work are given as:

$$
\begin{gathered}
W_{i}=P_{m i} \times V_{H}=\int_{0}^{720} P d V \\
N_{i}=\frac{W_{i} \times n}{60 \times 2}
\end{gathered}
$$

where $W_{i}$ is indicated work done per cycle $(\mathrm{J}), P_{m i}$ is mean indicated pressure $(\mathrm{Pa}), V_{H}$ is cylinder displacement $\left(\mathrm{m}^{3}\right), \mathrm{P}$ is pressure which was measured from the cylinder $(\mathrm{Pa}), \mathrm{V}$ is calculated instant cylinder volume $\left(\mathrm{m}^{3}\right), N_{i}$ is indicated engine power $(\mathrm{kW})$. [17].

Indicated engine torque can be calculated as given in equation (8) by the use of indicated power value

$$
M_{i}=\frac{60}{2 \pi n} N_{i}
$$

where $\mathrm{n}$ is the engine speed (rpm) and $M_{i}$ is indicated engine torque (Nm).

In order to obtain engine performance characteristics, the calculated engine power value, measured pressure and flow rates of gasoline, methane and $\mathrm{CO}_{2}$ can be used.

Equation (5) is used for the calculation of indicated thermal efficiency [17].

$$
\eta_{T i}=\frac{N_{i}}{\dot{m}_{g} \times L H V_{g}+\dot{m}_{H} \times L H V_{B}}
$$

where, $\eta_{T i}$ is indicated thermal efficiency, $\dot{m}_{g}$ and $\dot{m}_{C O 2}$ are mass flow rates of gasoline and $\mathrm{CO}_{2}$ respectively $(\mathrm{kg} / \mathrm{s})$ and $L H V_{g}$ and $L H V_{C O 2}$ are lower heating values of gasoline and $\mathrm{CO}_{2}$ respectively $(\mathrm{kJ} / \mathrm{kg}$ ).

For the calculation of emission values, which were also measured by volume and mass flow rate of exhaust gases during tests, measured flow rates of intake air, methane, $\mathrm{CO}_{2}$ and gasoline can be used as seen equation (6) [15]. Thereby, by using these values and indicated engine power, specific emissions can be calculated as given in equation (7) [15].

$$
\begin{aligned}
& \dot{m}_{e x}=\dot{m}_{i a}+\dot{m}_{H}+\dot{m}_{g} \\
& E P_{i}=E V_{i} x \frac{M_{i}}{M_{e x}} \times \frac{\dot{m}_{e x}}{N_{i}}
\end{aligned}
$$

where $\dot{m}_{e x}$ and $\dot{m}_{i a}$ is mass flow rates of exhaust gases and intake air, respectively (g/h), $E P_{i}$ is specific emission value of relevant gases $(\mathrm{g} / \mathrm{kWh}), E V_{i}$ is relevant gases and total exhaust gases ratio by volume for $\mathrm{CO}$ and by ppm for THC and $\mathrm{NO}_{\mathrm{x}}$ emissions, $M_{i}$ and $M_{e x}$ are molar mass of relevant gases and exhaust gases respectively $(\mathrm{kg} / \mathrm{kmol})$ and $N_{i}$ is indicated engine power $(\mathrm{kW})$.

The total propagated uncertainty of the Precision and Systematic (Bias) errors measurement determined by Kline and McClintock analysis [18] is:

$$
\left(W_{R}\right)_{P, B}=\left[\left(\frac{\partial R}{\partial x_{1}} w_{1}\right)^{2}+\left(\frac{\partial R}{\partial x_{2}} w_{2}\right)^{2}+\cdots+\left(\frac{\partial R}{\partial x_{n}} w_{n}\right)^{2}\right]^{1 / 2}
$$

And the computation of the total uncertainty $W_{R}$ is done with: 
Journal of Thermal Engineering, Research Article, Vol. 5, No. 6, Special Issue 10, pp. 131-140,

December, 2019

$$
W_{R}=\sqrt{\left(W_{R}\right)_{P}{ }^{2}+\left(W_{R}\right)_{B}{ }^{2}}
$$

where $\left(W_{R}\right)_{P, B}$ denotes the propagated uncertainty for either precision error $\left(W_{R}\right)_{P}$, or systematic (Bias) error $\left(W_{R}\right)_{B}$ functions. $\mathrm{x}_{1}, \mathrm{x}_{2}, \ldots, \mathrm{x}_{\mathrm{n}}$ are the measured variables and $\mathrm{w}_{1}, \mathrm{w}_{2}, \ldots \mathrm{w}_{\mathrm{n}}$ are the corresponding uncertainties of the variables. The measurement uncertainty values of test setup were given in Table 2.

Table 2. Accuracy values of test devices and obtained total uncertainty values

\begin{tabular}{|l|l|l|}
\hline Parameter & Device & Accuracy \\
\hline Engine speed & Incremental encoder & $\pm 5 \mathrm{rpm}$ \\
\hline Gasoline flow rate & Biotech VZS-005 & $\pm 1 \%$ (of reading) \\
\hline $\mathrm{CO}$ & AVL Digas 4000 & $0.01 \%$ Vol. \\
\hline $\mathrm{THC}$ & AVL Digas 4000 & $1 \mathrm{ppm}$ \\
\hline $\mathrm{NO}_{\mathrm{x}}$ & AVL Digas 4000 & $1 \mathrm{ppm}$ \\
\hline Calculated results & & Uncertainty value \\
\hline Indicated thermal efficiency & $\pm 1.18 \div 1.32 \%$ \\
\hline
\end{tabular}

\section{RESULTS AND DISCUSSION}

\section{ITE}

The efficiency of useful energy conversion from the fuel consumed by the engine is defined by indicated thermal efficiency. In other words, the engine specific fuel consumption is directly affected by ITE [17]. The variation in indicated thermal efficiency due to biogas usage at different $\mathrm{CO}_{2}$ ratios is given in Figure 2.

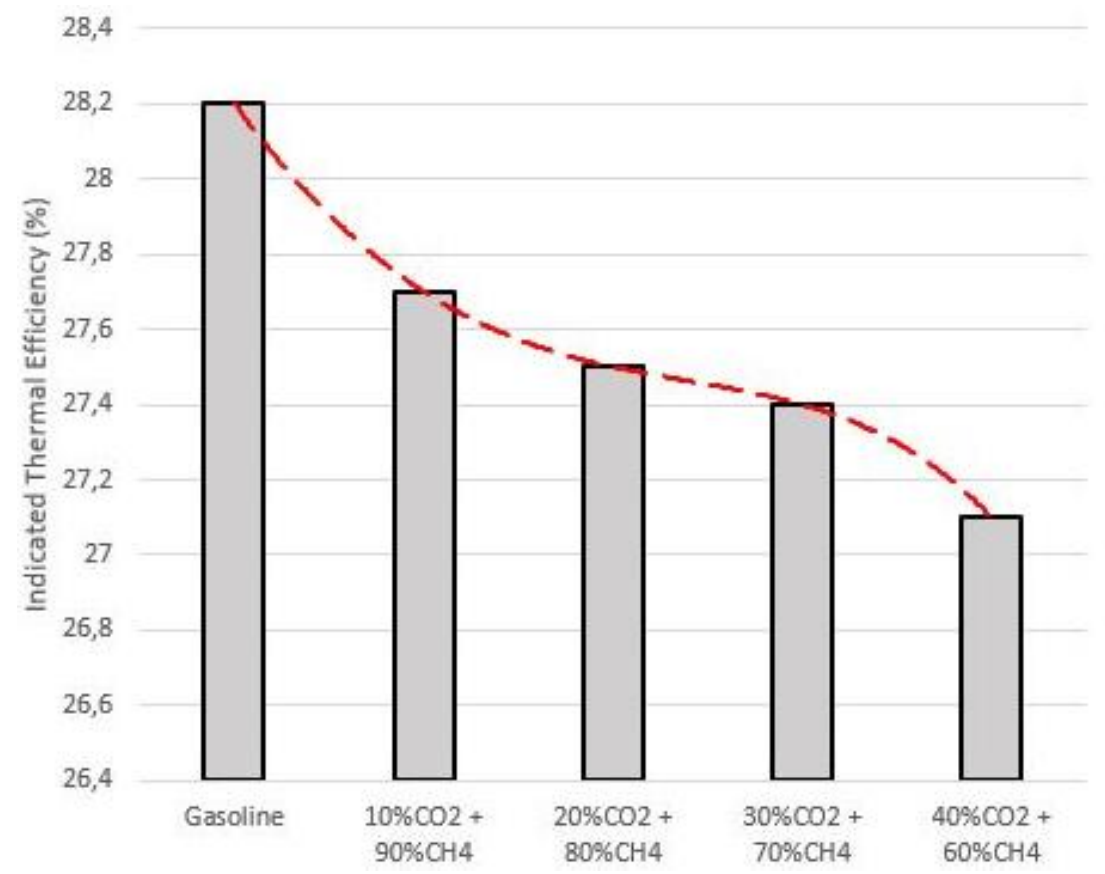

Figure 2. Effect of different level of $\mathrm{CO} 2$ and $\mathrm{CH} 4$ addition on indicated thermal efficiency

As comparison with the results when the engine is operated with only gasoline, ITE value is reduced at all $\mathrm{CO}_{2}$ ratios with biogas usage as fuel. ITE value decreased $1.8 \%$ at $10 \% \mathrm{CO}_{2}$ ratio, $2.4 \%$ at $20 \mathrm{CO}_{2}$ ratio, $2.8 \%$ at $30 \% \mathrm{CO}_{2}$ ratio and decreased $3.9 \%$ at $40 \% \mathrm{CO}_{2}$ ratio. 
The heat carrying capacity of $\mathrm{CO}_{2}$ in the biogas causes reduction of in-cylinder combustion pressure values [20]. This situation explains the reduction of ITE values with biogas usage which contains $\mathrm{CO}_{2}$.

\section{IMEP}

Through the cycle, in-cylinder pressure of an engine changes continuously. In order to estimate an average value of in-cylinder pressure variation, mean effective pressure parameter is defined [19]. Because of independency of engine speed and size, using mean effective pressure is a good way to compare engines in terms of design and output [19]. Indicated mean effective pressure (IMEP) is obtained by using indicated work to define mean effective pressure value of the engine [17]. In this study, indicated mean effective pressure (IMEP) parameter is used to compare engine performance of gasoline and biogas blends.

Figure 3 gives the test results about the variation of IMEP with the usage of only gasoline as fuel and with only biogas at four different $\mathrm{CO}_{2}$ ratios $(\% 10, \% 20, \% 30$ and \%40) at constant engine speed (2800 rpm). In comparison with the results when the engine is operated with only gasoline, IMEP value is reduced at all $\mathrm{CO}_{2}$ ratios with biogas usage as fuel. IMEP value decreased $\% 8.9$ at $\% 10 \mathrm{CO}_{2}$ ratio, $\% 9.4$ at $20 \mathrm{CO}_{2}$ ratio, $\% 10.5$ at $\% 30 \mathrm{CO}_{2}$ ratio and decreased $\% 12.2$ at $\% 40 \mathrm{CO}_{2}$ ratio.

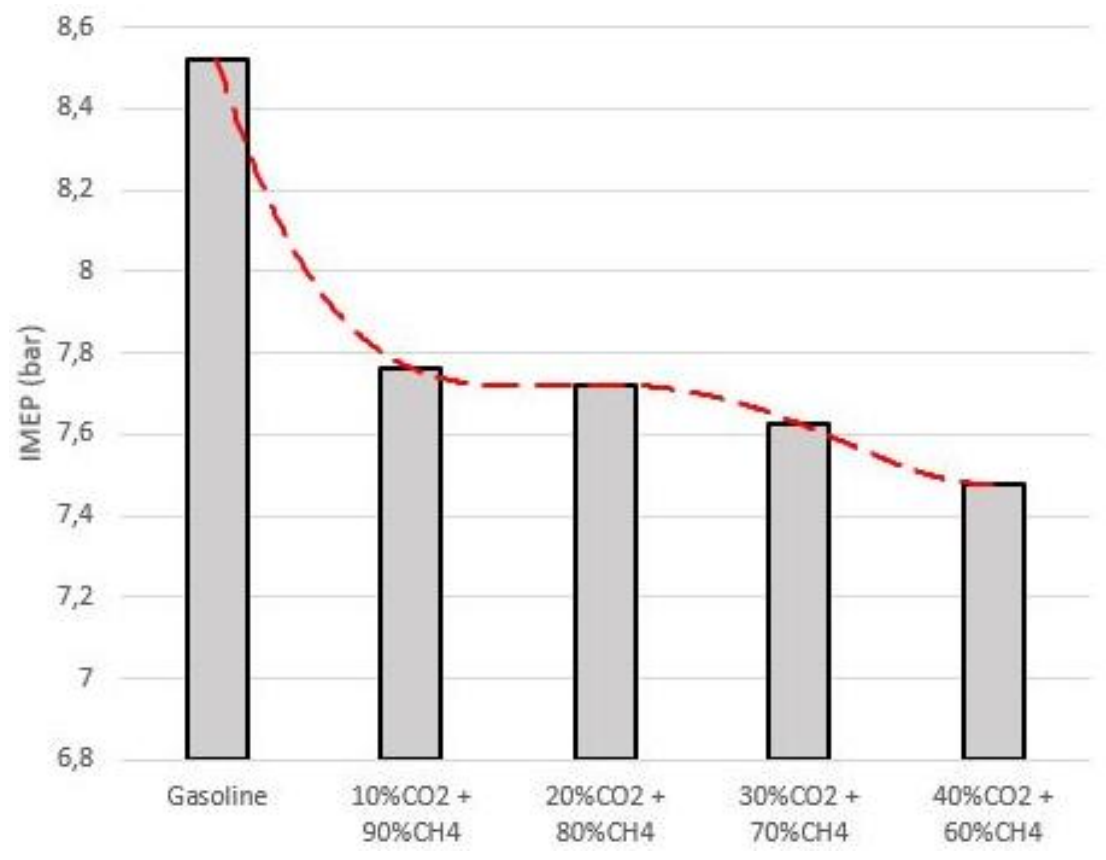

Figure 3. Effect of using $\mathrm{CH}_{4}$ at different $\mathrm{CO}_{2}$ levels on indicated mean effective pressure

As seen in Figure 3, with use of biogas and increasing $\mathrm{CO}_{2}$ content, IMEP values decreases. The main reason of this result is the decrease in maximum in-cylinder pressure because of operating the engine at near stoichiometric conditons. Also, because of using gaseous fuel, low density of methane, methane's rendering high cylinder volume and dilution of combustion chamber by $\mathrm{CO}_{2}$ (EGR effect) are the other reasons of the decrease in IMEP values.

\section{CO}

Carbon monoxide is a colorless, odorless, poisonous gas, which is mostly generated when engine is operated with rich fuel ratio [19]. When there is not enough $\mathrm{O}_{2}$ to convert all carbon to $\mathrm{CO}_{2}$, some fuel does not get burned and some carbon ends up as CO [19].

Figure 4 gives the test results about the variation of $\mathrm{CO}$ emission with the usage of only gasoline as fuel and with only biogas at four different $\mathrm{CO}_{2}$ ratios $(10 \%, 20 \%, 30 \%$ and $40 \%)$ at constant engine speed (2800 rpm). 


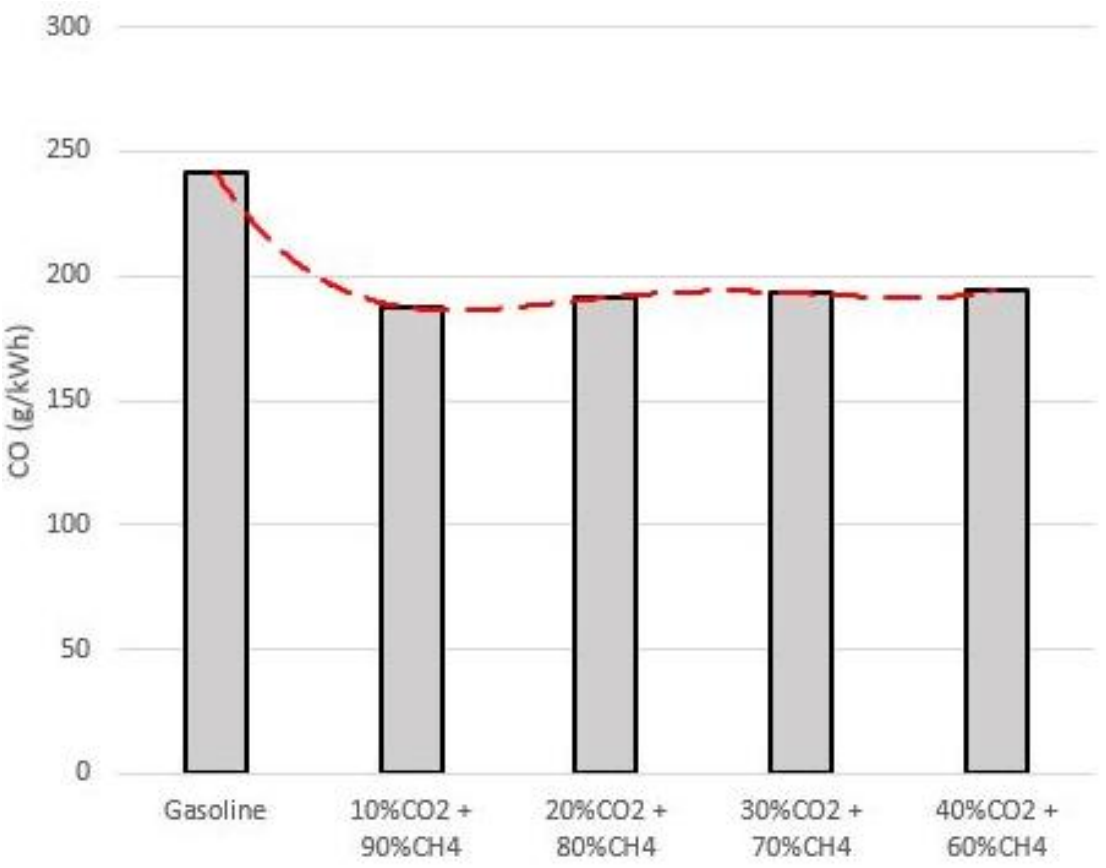

Figure 4. Effect of different level of $\mathrm{CO} 2$ and $\mathrm{CH} 4$ addition on specific $\mathrm{CO}$ emissions

As the comparison with only gasoline usage as fuel, $\mathrm{CO}$ emissions are low with only biogas usage at all $\mathrm{CO}_{2}$ ratios. $\mathrm{CO}$ emission reduces about $22,5 \%$ at $10 \% \mathrm{CO}_{2}$ ratio, reduces about $20,8 \%$ at $20 \% \mathrm{CO}_{2}$ ratio, reduces about $20 \%$ at $30 \% \mathrm{CO}_{2}$ ratio and reduces about $19,5 \%$ at $40 \% \mathrm{CO}_{2}$ ratio from $\mathrm{CO}$ emission released by engine operated with only gasoline.

Methane composes the main structure of biogas. Methane has low $\mathrm{C} / \mathrm{H}$ ratio and low carbon concentration in its composition. Because of its low $\mathrm{C}$ structure, methane increases the oxygenation of the fuel [21]. So, this situation explains the reduction in $\mathrm{CO}$ emission with use of biogas as fuel.

Methane has low $\mathrm{C}$ content, so it provides low $\mathrm{CO}$ emissions. $\mathrm{As}^{\mathrm{CO}_{2}}$ content of mixture increases, $\mathrm{CO}$ emissions slightly increases. However, methane is a reactive gaseous fuel, and with the use of methane, a nearly homogenous mixture occurs in combustion chamber. So, the changes in $\mathrm{CO}$ emissions at all $\mathrm{CO}$ contents are nearly negligible.

\section{THC}

As one of the reasons of lung and blood diseases, hydrocarbons are another harmful emission [22]. So, for human health, it is essential decrease in THC emission. THC is the definition of the hydrocarbon emissions which are emitted from tailpipe. It contains both partially burned and unburned hyrocarbons. $\mathrm{So}, \mathrm{CH}_{4}$ emissions are counted in total hyrocarbons and more accurate results are obtained. The measured THC emission values with only gasoline fuel and with biogas at four different ratios $(10 \%, 20 \%, 30 \%$ and $40 \%)$ at constant engine speed (2800 rpm) are given in Figure 5.

As compared with only gasoline usage as fuel, hydrocarbon emissions were increased considerably with the use of biogas at all $\mathrm{CO}_{2}$ ratios. THC emissions increased at about $2.4 \%$ at $10 \% \mathrm{CO}_{2}$ ratio, increased about $6.6 \%$ at $20 \% \mathrm{CO}_{2}$ ratio, increased about $8.7 \%$ at $30 \% \mathrm{CO}_{2}$ ratio and increased about $11.2 \%$ at $40 \% \mathrm{CO}_{2}$ ratio in comparison with gasoline. 


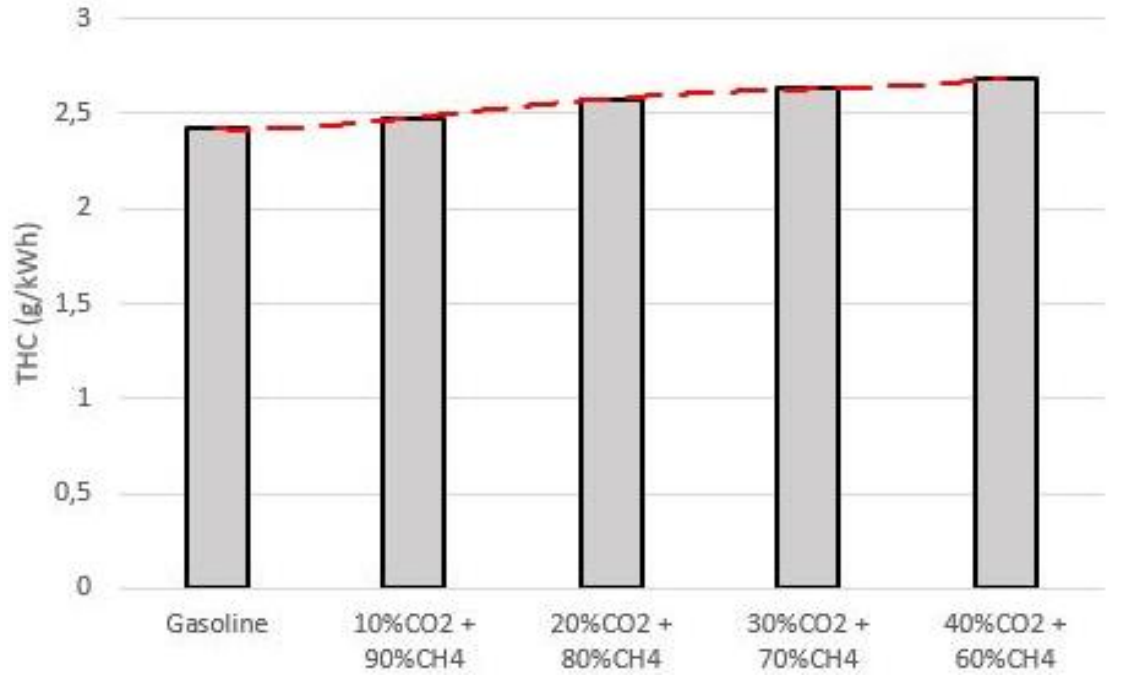

Figure 5. Effect of different level of $\mathrm{CO}_{2}$ and $\mathrm{CH}_{4}$ addition on specific THC emissions

Biogas contains high concentration of methane. Because of the high quenching distances and zones of methane and its volatile HC structure, THC emissions increase with biogas usage as fuel [23]. For optimal usage of biogas, crevice zones, electrode gaps, valve seats, piston ring gaps and sealing gaps in the engine should be minimized. The unsuitable design of the SI engine for biogas fuel is another reason of the increase in THC emissions.

\section{$\mathrm{NO}_{x}$}

Oxides of nitrogen, which is emitted by an engine, can reach to $2000 \mathrm{ppm}$ value. Nitrogen in the air is the main source of $\mathrm{NO}_{\mathrm{x}}$. Released $\mathrm{NO}_{\mathrm{x}}$ is one of the major reasons of photochemical smog [19]. Nowadays, emission regulations become more stringent, especially for $\mathrm{NO}_{\mathrm{x}}$ emissions. Because of stringent emission regulations, SI engines are being named as positive ignition engine as they are compared with diesel engines in terms of released amount of $\mathrm{NO}_{\mathrm{x}}$ emissions. Methane has additive effect on NOx emissions. In this study, because of high methane percentage of fuel, NOx emissions are higher than that of pure gasoline at $10 \%$ and $20 \%$ contents.

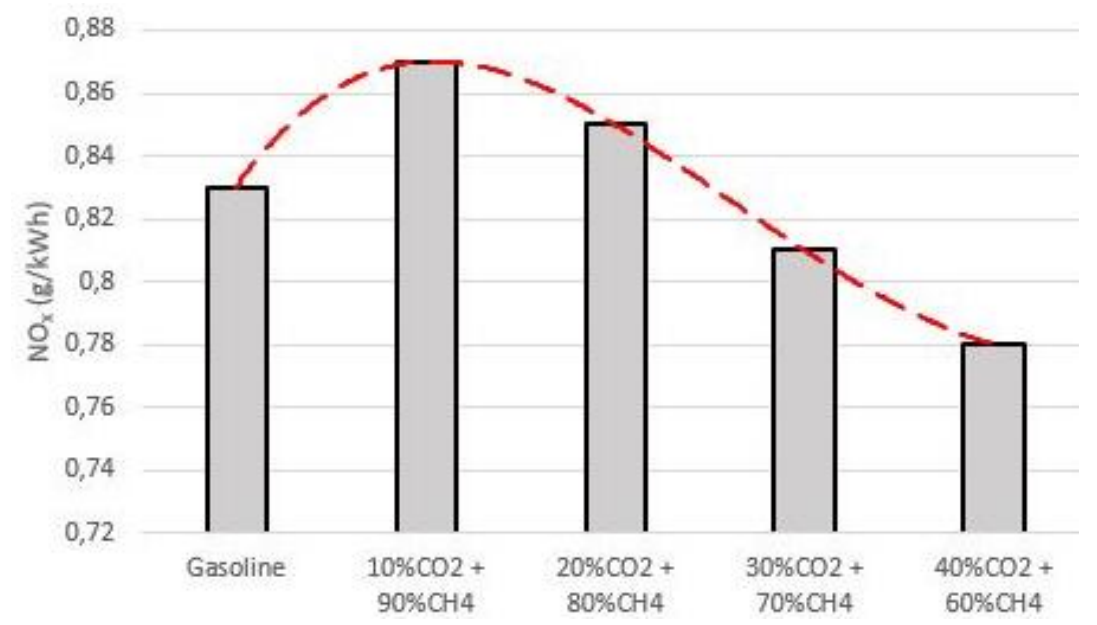

Figure 6. Effect of different level of $\mathrm{CO}_{2}$ and $\mathrm{CH}_{4}$ addition on specific $\mathrm{NO}_{\mathrm{x}}$ emissions

$\mathrm{NO}_{\mathrm{x}}$ emissions are shown in Figure 6 with biogas at different $\mathrm{CO}_{2}$ ratios $(10 \%, 20 \%, 30 \%$ and $40 \%)$ and with only gasoline at constant engine speed ( $2800 \mathrm{rpm})$. 
When compared to only gasoline usage, $\mathrm{NO}_{\mathrm{x}}$ emissions raise about $\% 4.8$ with biogas at $\% 10 \mathrm{CO}_{2}$ ratio, and raises about $2.4 \%$ at $20 \% \mathrm{CO}_{2}$ ratio. Then, $\mathrm{NO}_{\mathrm{x}}$ emissions decreases at about $2.4 \%$ with biogas at $30 \% \mathrm{CO}_{2}$ ratio and decreases at about $6 \%$ at $40 \% \mathrm{CO}_{2}$ ratio.

As seen in the results, with the usage of biogas, $\mathrm{NO}_{\mathrm{x}}$ emissions increase because of the increased local peak in-cylinder pressure, but when $\mathrm{CO}_{2}$ ratio in the biogas reaches to $30 \%$ and upper values, there can be seen a decrease in $\mathrm{NO}_{\mathrm{x}}$ emissions, The main reason of this decrease is the heating capacity of $\mathrm{CO}_{2}$ and its decreasing $\mathrm{O}_{2}$ availability in combustion process [24].

\section{CONCLUSIONS}

In this study, in a single cylinder, $270 \mathrm{cc}$, naturally aspirated, four stroke SI engine, at stoichiometric condition and constant engine speed (2800 rpm), effect of biogas fuel at different $\mathrm{CO}_{2}$ ratios $(10 \%, 20 \%, 30 \%$ and $40 \%$ ) on engine performance and emissions was investigated with comparison of only gasoline usage.

The main conclusions were summarized below:

- With the increasing $\mathrm{CO}_{2}$ ratio, there has been a decrease in indicated mean effective pressure. The main reason of this situation is stoichiometric working conditions and the low heating value (by volume) of biogas. ITE value decrease with use of biogas and increasing ratio of $\mathrm{CO}_{2}$

- With use of biogas and increasing $\mathrm{CO}_{2}$ content, IMEP values decreases. The main reason of this result is the decrease in maximum in-cylinder pressure because of operating the engine at near stoichiometric condition. Also, because of using gaseous fuel, low density of methane, methane's rendering high cylinder volume and dilution of combustion chamber by $\mathrm{CO}_{2}$ (EGR effect) are the other reason's of the decrease in IMEP values.

- $\mathrm{CO}$ emissions decrease with biogas usage. The low $\mathrm{C} / \mathrm{H}$ ratio of methane, which is main component of biogas, is the main cause of the decrease in $\mathrm{CO}$. THC emissions increases as the $\mathrm{CO}$ content in biogas increases. The unsuitable design of the engine for methane fuel, the crevice zones in combustion chamber and the structure of methane which is already an unburned $\mathrm{HC}$ are the other reasons of increase in $\mathrm{THC}$ emission.

- Because of the increase in local peak in-cylinder pressure values with biogas usage, $\mathrm{NO}_{\mathrm{x}}$ emissions increase also. However, when $\mathrm{CO}_{2}$ ratio in biogas reach $30 \%$ and upper values, because of $\mathrm{CO}_{2}$ 's heating capacity and decreasing $\mathrm{O}_{2}$ availability, $\mathrm{NO}_{\mathrm{x}}$ emission values are under the values which are taken with only gasoline usage. Although it has some negative impact on engine performance, biogas usage in SI engines can simulate EGR effect, so it can be possible to control the $\mathrm{NO}_{\mathrm{x}}$ emissions.

\section{NOMENCLATURE}

$\begin{array}{ll}\mathrm{CA} & \text { Crank angle } \\ \mathrm{CH}_{4} & \text { Methane } \\ \mathrm{CO} & \text { Carbon monoxide } \\ \mathrm{CO}_{2} & \text { Carbon dioxide } \\ \mathrm{EGR} & \text { Exhaust gas recirculation } \\ \mathrm{HC} & \text { Hydrocarbons } \\ \mathrm{IMEP} & \text { Indicated Mean Effective Pressure } \\ \mathrm{ITE} & \text { Indicated Thermal Efficiency } \\ \mathrm{NO}_{\mathrm{x}} & \text { Oxides of nitrogen } \\ \mathrm{PM} & \text { Particulate matter } \\ \mathrm{SI} & \text { Spark ignition } \\ \mathrm{THC} & \text { Total unburned hydrocarbons }\end{array}$

\section{REFERENCES}

[1] European Environment Agency. (2017). Monitoring CO2 emissions from new passenger cars and vans in 2016. Report No 19/2017. Copenhagen: EEA.

[2] European Automobile Association. (2017). Economic and Market Report: key takeaways about the EU industry for 2016. ACEA 
Journal of Thermal Engineering, Research Article, Vol. 5, No. 6, Special Issue 10, pp. 131-140,

December, 2019

[3] European Environment Agency. (2016). Air Quality in Europe - 2016 Report. Report No 28/2016. Copenhagen: EEA.

[4] Koten, H. (2018). Performance analysis of a diesel engine within a multi-dimensional framework. Journal of Thermal Engineering (JTEN), Vol. 4, 2075-2082.

[5] Environment Pollution (Prevention and Control) Authority for the National Capital Region (EPCA). (2017). Comprehensive Action Plan for air pollution control. Report No. 70. Delhi: EPCA.

[6] Demirci, A., Koten, H., Gumus, M. (2018). The effects of small amount of hydrogen addition on performance and emissions of a direct injection compression ignition engine. Thermal Science. 22. 4-4. 10.2298/TSCI170802004D

[7] Porpatham, E., Ramesh, A., Nagalingam, B. (2013). Effect of swirl of a biogas fuelled spark ignition engine. Energy Conversion and Management, 76, 463-471.

[8] Nunes de Faria, M., Bueno, J., Ayad, S., Belchior, C. (2017). Thermodynamic simulation model for predicting the performance of spark ignition engines using biogas as fuel. Energy Conversion and Management, $149,1096-1108$.

[9] Nadaleti, C.W., Przybyla, G. (2018). Emissions and performance of a spark-ignition gas engine generator operating with hydrogen-rich syngas, methane and biogas blends for application in southern Brazillian rice industries. Energy, 154, 38-51.

[10] Karagoz, M., Kurtgoz, Y., Deniz, E. (2017) Biogas engine performance using ANN. Engineering Science and Technology, an International Journal, 20, 1563-1570.

[11] Wang, C., Kan, X., Zhou, D., Yang, W., Zhai, X. (2018) An investigation on utilization of biogas and syngas produced from biomass waste in premixed spark ignition engine. Applied Energy. 212, 210-222.

[12] Kwon, E., Song, K., Kim, M., Shin, Y., Choi, S. (2017). Performance of small spark ignition engine fueled with biogas at different compression ratio and various carbon dioxide dilution. Fuel, 196, 217-224.

[13] Nadaleti, C.W, Przybyla, G. (2018). SI engine assessment using biogas, natural gas and syngas with different content of hydrogen for application in Brazillian rice industries: Efficiency and pollutant emissions. Int J. Hyydrogen Energy, 1-14.

[14] Porpatham, E., Ramesh, A., Nagalingam, B. (2018) Experimental studies on the effects of enhancing the concentration of oxygen in the inducted charge of a biogas fuelled spark ignition engine. Energy, 142, 303-312.

[15] Yadav, S.D., Kumar, B., Thipse, S. (2013). Characteristics of biogas operated automotive SI engine to reduce exhaust emissions for green development. (No. 2013-26-0012). SAE Technical Paper.

[16] VDMA Engines and Systems. (2017). Exhaust emission legislation diesel- and gas engines. Frankfurt: VDMA.

[17] Heywood, J.B. (1988). Internal combustion engine fundamental. McGraw-Hill Education.

[18] Kline, S.J., McClintock, F.A. (1953). Describing uncertainties in single-sample experiments. Mech Eng, 75, $3-8$.

[19] Pulkrabek, W. (2004). Engineering fundamentals of the internal combustion engines. Prentice Hall, New Jersey.

[20] Chuayboon, S., Prasertsan, S., Theppaya, T., Maliwan, K., Prasertsan, P. (2014). Effects of $\mathrm{CH}_{4}, \mathrm{H}_{2}$ and $\mathrm{CO}_{2}$ mixtures on SI Gas engine. Energy Procedia, 52, 659-665.

[21] Koten, H., Gul, M. Z. (2014). Multidimensional Modelling of Compressed Bio Gas (CBG) Engine For Ultra Low Emission. International Journal of Pure and Applied Sciences, 26(2), 41-49.

[22] Degobert, P. (1995). Automobiles and Pollution. Warrendale: SAE Society of Automotive Engineers Inc., Paris: Editions Technip.

[23] Koten, H., Yilmaz, M., Gul, M.Z. (2014). Compressed biogas-diesel dual-fuel engine optimization study for ultralow emission. Advances in Mechanical Engineering. Article ID 571063. http://dx.doi.org/10.1155/2014/571063

[24] Koten, H. (2017). Usage of biogas in a diesel engine: Compressed bio gas (CBG). LAP Lambert Academic Publishing. ISBN-13:978-3-330-07965-6. 